\title{
Management of Crohn's Anal Strictures: The Experience of a Department of Medicine
}

\author{
Azib N*, El Bacha H, Benzzoubeir N, Ouazzani L, Errabih I
}

Department of Medicine B, Ibn Sina University Hospital, Rabat

DOI: $10.36347 /$ sjams.2020.v08i05.003

| Received: 24.04.2020 | Accepted: 01.05.2020 | Published: 06.05.2020

*Corresponding author: Azib N

Abstract

Original Research Article

Crohn's disease is a chronic inflammatory disorder of the gastrointestinal tract. Perineal manifestations are a marker for disease severity. Anal strictures result from fibrotic scarring after several inflammatory attacks and are responsible for impaired quality of life. The aim of our work is to study the epidemiological profile and the management of these lesions. Methods: This is a descriptive retrospective study over a 17-year period from January 2002 to January 2019 , concerning a monocentric cohort of 1053 cases of Crohn's disease. Results: 22 patients had anal stricture, a prevalence rate of $2.08 \%$. The main symptoms were painful passing of stools in all patients, emission of pus in 12 patients $(54.5 \%)$ cases, imperiosity in 5 patients $(22.7 \%)$, abdominal pain in 10 patients $(45.4 \%)$ and an obstructed defecation syndrome in 3 patients (13.6\%). Penetrating phenotype B3 and the colonic localization L2 were the most frequent. Pelvic MRI confirmed anal stenosis in all patients, associated with complex fistulas PARKS grade 4 in $18 \%(\mathrm{n}=4)$ cases. Treatment of the stenosis consisted of finger dilatation in 21 patients (90\%), associated with dilation by Hegar dilatators in $63.6 \%(n=14)$ cases and by balloon in $31.8 \%(n=7)$ cases; the stenosis biopsy revealed squamous cell carcinoma in only one case, $4.5 \%$. Medical treatment for CD was based on immunosuppressants in $72.7 \%(\mathrm{n}=16)$ cases, anti TNF in $18.18 \%(n=4)$ cases and Combination therapy in $9 \%(n=2)$ cases. Conclusion: The prevalence of anal strictures in our study remains low compared to literature series; these are young women with LAP, a Penetrating phenotype and pancolitis.

Keywords: Crohn's Anal Strictures, Hegar gastrointestinal.

Copyright @ 2020: This is an open-access article distributed under the terms of the Creative Commons Attribution license which permits unrestricted use, distribution, and reproduction in any medium for non-commercial use (NonCommercial, or CC-BY-NC) provided the original author and source are credited.

\section{INTRODUCTION}

Anperineal involvement of Crohn's disease represents all lesions attributed to the disease, which affect anal canal, perineal skin, lower rectum and rectovaginal septum. The main elementary lesions are represented by ulcers, suppurations and strictures. The problem of anal stricture is based on the therapeutic modalities and the commitment of functional prognosis. Our study aims, assess prevalence of anal strictures during perineal Crohn's disease, and focus on the management of anal strictures.

\section{METHODS}

We conducted a retrospective descriptive analytical monocentric study, over a period of 17 years going from 2002 to 2019, about Crohn's disease patients with anal stenosis.

We included all patients with Crohn's disease associated with anal stenosis defined clinically by difficulty on evacuation or by continence disorder (imperiosity, false needs, and mucus), admitting small or no fingertips based on the Cardiff classification and confirmed by imaging which shows a thickening of the anal canal. Disappearance of stenosis was defined by ability of colonoscope to cross the anal canal. We excluded all patients with non-Crohnien anal strictures.

We studied the following characteristics: Age, sex, history, Clinical digestive and proctological symptomatology, endoscopy, pathology and imaging data. We used the Montreal classification to study phenotype and localization of Crohn's disease. Then we noted the type of therapeutic management (medical, instrumental or surgical treatment) and the result of each of these therapeutic strategies.

\section{RESULTS}

We included 22 patients with anal strictures out of a total of 1053 patients with Crohn's disease, an average of $2.08 \%$. The characteristics of our patients have been summarized in Table 1 . The average age of our patients was 37 years $+/-9.3$, with extremes ranging 
from 20 to 66 years; woman predominance was noted with a sex ratio $\mathrm{H} / \mathrm{F}$ from 4/18. Clinically: on the digestive level, abdominal pain was present in $45.4 \%$ of cases $(n=10)$, bloody mucus in stool in $41 \%$ of cases $(n$ $=9$ ) obstructed defecation syndrome in 3 patients (13.6\%). Proctologically, the symptoms were represented by painful passing in all patients, emission of pus in 12 patients $(54.5 \%)$, positional pain in 2 patients $(9 \%)$, and imperiosity in 5 patients $(22.7 \%)$. On proctological examination, anal strictures were classified according to the Cardiff classification in: S1 (admitting finger pulp) in 7 patients $(31.8 \%$ ) (fig1). S2 (not admitting finger pulp) in 15 patients $(68.2 \%$ ) (Fig 2). 6 patients $(27.27 \%)$ had associated ulcers, 5 patients $(83.3 \%)$ classified U1 and one patient $(16.6 \%)$ U2. Anal fistulas were present in 13 patients $(59 \%)$ distributed as follows: 4 patients classified F1 (30.7\%). 9 patients classified F2 (69.2\%).

The penetrating phenotype B3 and the colonic localization L2 were the most frequent with respectively 12 cases $(54.5 \%)$ and 10 cases $(45.4 \%)$. All our patients benefited from pelvic MRI, which showed fibrous anal stenosis in $95.45 \%(n=21)$ cases, complex fistulas in $41 \%(n=9)$ cases, and locally advanced rectal cancer in a single case, $4.5 \%$ of patients. None of our patients have had endoscopic ultrasound because of anal stenosis. The stricture biopsy made systematically revealed a case of squamous cell carcinoma. The medical treatment of $\mathrm{CD}$ was immunosuppressants in $72.72 \%(\mathrm{n}=16)$ cases, anti TNF in $18.18 \%(\mathrm{n}=4)$ cases and combination therapy in $2(9 \%)$ patients. Specific stenosis treatment was dilation with Hegar dilatator in $66.6 \%(\mathrm{n}=14)$ cases, and balloon in $33.3 \%$ $(\mathrm{n}=7)$ cases (fig 3) associated in both cases with maintenance finger dilation in 21 patients $(95,45 \%)$. All patients with associated active fistula benefited from drainage with antibiotic therapy based on metronidazole and ciprofloxacin. 3 patients $(13.63 \%)$ had an associated colonic stenosis, they underwent colectomy with restoration of continuity, the medical treatment consisted for the patient who had an inflammatory stenosis an addition of Anti TNF, after a few months from the start of treatment, clinical improvement was noted. 16 patients received optimizated medical treatment. 16 patients improved after the first dilation session, one patient bled after balloon dilation. 4 patients had a recurrence of stenosis, a rate of $18 \%$. The latter benefit from a second dilation session, three patients responded. Definitive stoma was performed in one patient.

Table-1: Characteristics of the study population

\begin{tabular}{|l|l|}
\hline & $\mathbf{n}(\mathbf{\%})$ \\
\hline Gender (M/F) & $\mathbf{4} / \mathbf{1 8}$ \\
\hline Middle (age) & $\mathbf{3 7}$ years +/-9.3 \\
\hline B2- stricturing & $\mathbf{1 0}(\mathbf{4 5 , 4 5 \% )}$ \\
\hline B3- penetrating & $\mathbf{1 2 ( 5 4 , 5 \% )}$ \\
\hline L1-ileal & $\mathbf{3}(\mathbf{1 3 , 6 \%})$ \\
\hline L2-colonic & $\mathbf{1 0}(\mathbf{4 5 \%})$ \\
\hline L3-ileocolonic & $\mathbf{9 ( 4 1 \% )}$ \\
\hline stricture & $\mathbf{2 2 ( 2 . 0 8 \% )}$ \\
\hline S1 & $\mathbf{7 ( 3 1 , 8 \% )}$ \\
\hline S2 & $\mathbf{1 5}(\mathbf{6 8 , 2 \%})$ \\
\hline Ulcers & \\
\hline U1 & $\mathbf{5 ( 8 3 , 3 \% )}$ \\
\hline U2 & $\mathbf{1 ( 1 6 , 6 \% )}$ \\
\hline Fistula & \\
\hline F1 & $\mathbf{4 ( 3 0 , 7 \% )}$ \\
\hline F2 & $\mathbf{9 ( 6 9 , 2 \% )}$ \\
\hline Medical treatment before dilatation & \\
\hline Anti TNF & $\mathbf{4 ( 1 8 , 8 \% )}$ \\
\hline $\begin{array}{l}\text { Immunosuppressant } \\
\text { (AZA or 6MP) }\end{array}$ & $\mathbf{1 6}(\mathbf{7 2 , 7 2 \%})$ \\
\hline Combination therapy & $\mathbf{2 ( 9 \% )}$ \\
\hline Colectomy (colonic stricture) & $\mathbf{3 ( 1 3 , 6 3 \% )}$ \\
\hline Anal dilation (finger, bougies, balloon) & $\mathbf{2 1 ( 9 5 , 4 \% )}$ \\
\hline Second dilation & $\mathbf{4 ( 1 8 \% )}$ \\
\hline improved medical treatment. & $\mathbf{1 6}(\mathbf{7 2 , 7 \%})$ \\
\hline Definitive stoma & $\mathbf{1 ( 4 , 5 4 \% )}$ \\
\hline
\end{tabular}




\section{DISCUSSION}

Perineal Crohn's disease (PCD) includes nonfistulizing manifestations (cracks, ulcers and strictures) and fistulizing lesions (fistulas, abscesses and rectovaginal fistulas). Superficial cracks represented 21 to $35 \%$ of perineal lesions, anal and rectal ulcers 5 to $10 \%$ and anorectal strictures 9 to $22 \%$ [1].

In 1992, the Cardiff classification classified stricture on a scale from 0 to $2(0=$ no stricture, $1=$ reversible stricture, $2=$ irreversible stricture) and according to the location of the stenosis, rectal or anal, S1 strictures are usually inflammatory, due to spasms, so S2 results from fibrous tissue.

In Brochard's study (2005 -2013) including 102 patients who had anorectal strictures, the male / female ratio was $37 / 65$. $63.7 \%$ of women with an average age of 41.2 years [2], predominance in the middle-aged adult women that we find in our study.

The main symptoms of anal stricture include anal pain, rectal bleeding and constipation. Rarely, patients report stains or diarrhea. Bowel pain remains the main symptom, in Brochard's study, found in 51\% patients [3] and in 69\% cases in another study [4].

Association of different anoperineal lesions is frequent, in a series including 282 patients, $94 \%$ of the stricture were associated with other lesions $(n=46 / 49)$ [5]. Other studies have shown a high prevalence between anal fistula and anorectal stricture $[6,2]$.

The Penetrating phenotype and colonic location were predominant, however the literature do not show a relationship between the luminal phenotype and perianal Crohn's disease phenotype.

Stenosis occurs after a long course of Crohn's disease. Initially, some studies suggested that the appearance of narrowing / anal strictures was the result of the healing process of inflammatory lesions [7, 8]. The role of biotherapies has been suspected for a time in the appearance or worsening of anorectal strictures, however, an under-analysis based on the TREAT register (the Crohn's Therapy, Resource, Evaluation, and Assessment Tool) has shown that the risk complications were similar in patients who received and did not receive infliximab [9].

Therapeutic management of Crohnian anal stenosis requires an endoscopic and radiological assessment beforehand, preferably by pelvic MRI. Mainly to characterize the length, the inflammatory or fibrous nature of the stenosis, and the presence of another perineal lesion $[10,11]$. In fact, the therapeutic attitude differs, depending on the inflammatory or fibrous nature of the stenosis. Concerning inflammatory strictures, basic treatment optimization is necessary [12].
Data from different European cohorts suggest a clinical advantage with anti TNF in Crohnian stricture $[13,14,1,15,16]$.

In Brochard's study, the adjustment of the background therapy, allowed a cure rate of anorectal strictures in more than $50 \%$ of patients after a follow-up period of 3 years. In our series, all the patients who had had an optimization of the background therapy have progressed well.

In the study by Bouguen et al. [1], out of 22 patients on infliximab with anorectal Crohn's stricture, 12 had a complete stricture regression after an average follow-up of 175 weeks: only 6 had anal dilation. It was unclear whether this was type 1 or 2 stenosis. An additional reported case described the use of vedolizumab in a patient with Crohn's disease complicated by anorectal stenosis with good evolution [17].

For short fibrous anal or anorectal strictures, no currently approved medication is known to prevent or reverse established fibrosis [18], dilation is the treatment of choice, it can be carried out simply with the finger, with a bougie dilatator (Hegar dilatators or metal olive dilatators) [19], or with balloons under general or locoregional anesthesia. A study on ten patients with S2 fibrous anal stenosis due to $\mathrm{CD}$ dilated by candles showed long-term efficacy [20]. This method provides tactile feedback, which makes it possible to estimate the degree of resistance to the dilatator passage, and thus avoid overdilation. Another study comparing bougies versus balloons in the treatment of benign postoperative rectal strictures, in a total of 39 patients did not objectify a statistically significant difference between the two groups concerning the success rate, major complications, number of necessary dilations, or recurrence, the only advantage was the low cost of the bougies [21]. In fact, unlike balloons, bougies are reusable. The intervals between dilations depend on the clinical examination. A new dilation is proposed as soon as a recurrence is noted without waiting for symptoms appearance.

Regarding complications, the risk of anal incontinence after anal dilatation is high due to fibrosis which is often associated with destruction of the anal sphincter. There is no hemorrhage, perforation or serious undesirable effects described after anal dilation in the literature, subject to very poor literature, on the other hand it must be carried out judiciously because of a risk of sepsis [20] only one case of bleeding was noted in our series.

If treatment by dilation fails, and before resorting to an ano-proctectomy, other conservative surgical alternatives may be considered [22, 23, 5]. In the event of short anal or low rectal stenosis, two techniques of plasty can be proposed. One is to 
vertically incise the stenosed area and then suture the banks transversely as for intestinal stricturoplasty. The other is to excise the stenotic fibrous area over part of the circumference and to cover the defect with a rectal advancement flap. These techniques are only possible in the absence of inflammatory luminal involvement and are in fact rarely performed. They have not been evaluated to date.

The risk of anal cancer in Crohn's disease remains underestimated. In a systematic literature review, published by Slesser et al. [24], the incidence of anal cancer in Crohnian patients was $(2.0$ / 100,000), mainly Crohn's disease with LAP $85 \%$.

Another recent controlled study of 53,568 patients with UC and CD indicated that the prevalence of cancer was higher in patients with stenosis [25]. This requires regular monitoring patients with crohn's anal lesions, and to perform biopsies [26] (Fig4).

In case of stenosis with ano-perineal suppuration it is recommended before dilating to treat luminal disease and associated ano-perineal lesions by optimizing background treatment and draining the suppurations.

\section{Conclusion}

Anal stenosis usually occurs after several flareups inflammatory and is often late in the course of the disease. The therapeutic strategy requires medicosurgical concertation.

The increased risk of dysplasia in these patients requires regular monitoring with biopsies.

In the case of inflammatory stenosis, a basic treatment of $\mathrm{CD}$ is proposed as a first intention before dilation in the event of failure.

Dilatation is proposed as a first line in case of fibrous, symptomatic and short stenosis or when it makes endoscopic monitoring impossible and / or when it does not allow the drainage of suppuration.

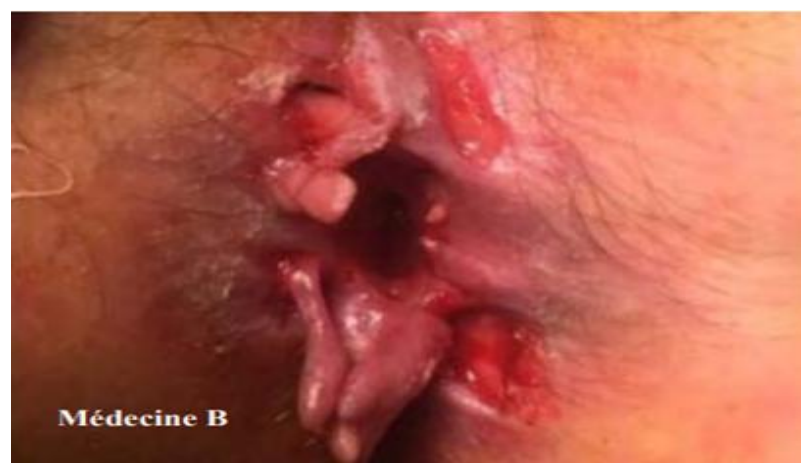

Fig-1: pseudocondylomatous tumors. With 2 major ulcers and fibrous stricture admitting the fingertip (S1)

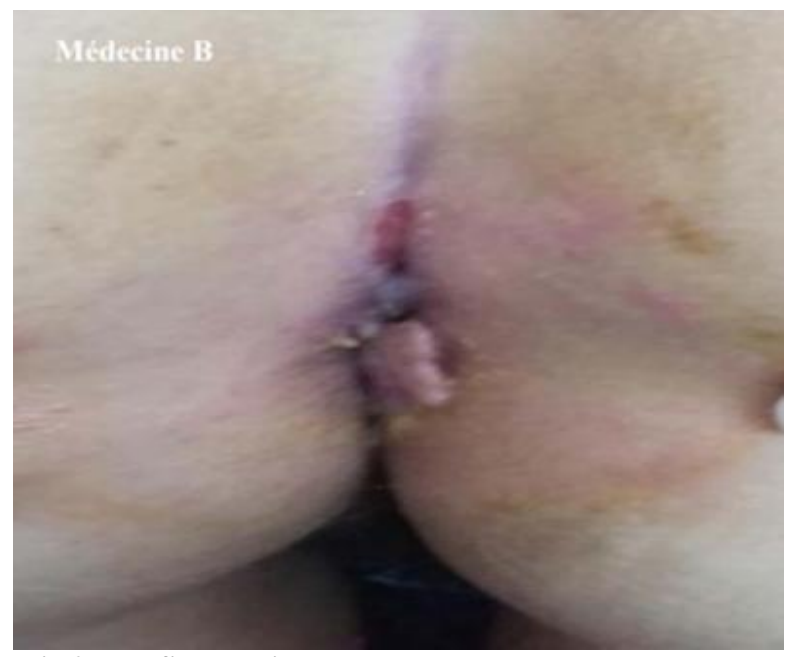

Fig-2: anal fistulas with pseudocondylomatous tumors and anal stricture (S2)

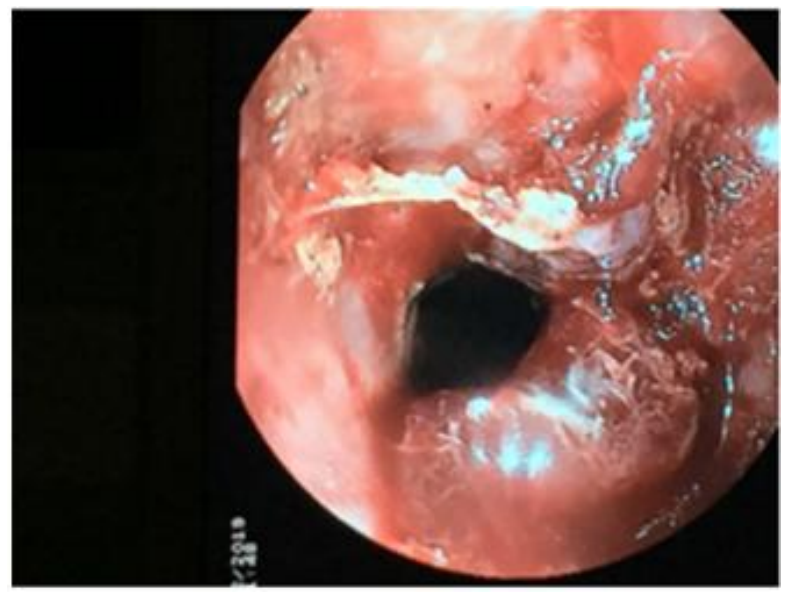

Fig-3A: Endoscopic view of anal stricture dilatation with hydrostatic balloon (Before dilatation)

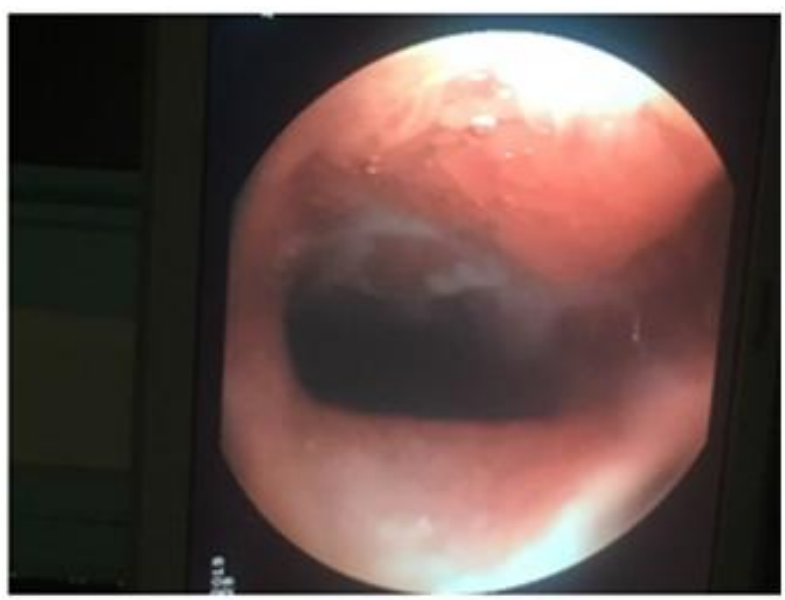

Fig-3B: Endoscopic view of anal stricture dilatation by a hydrostatic balloon (After dilatation) 


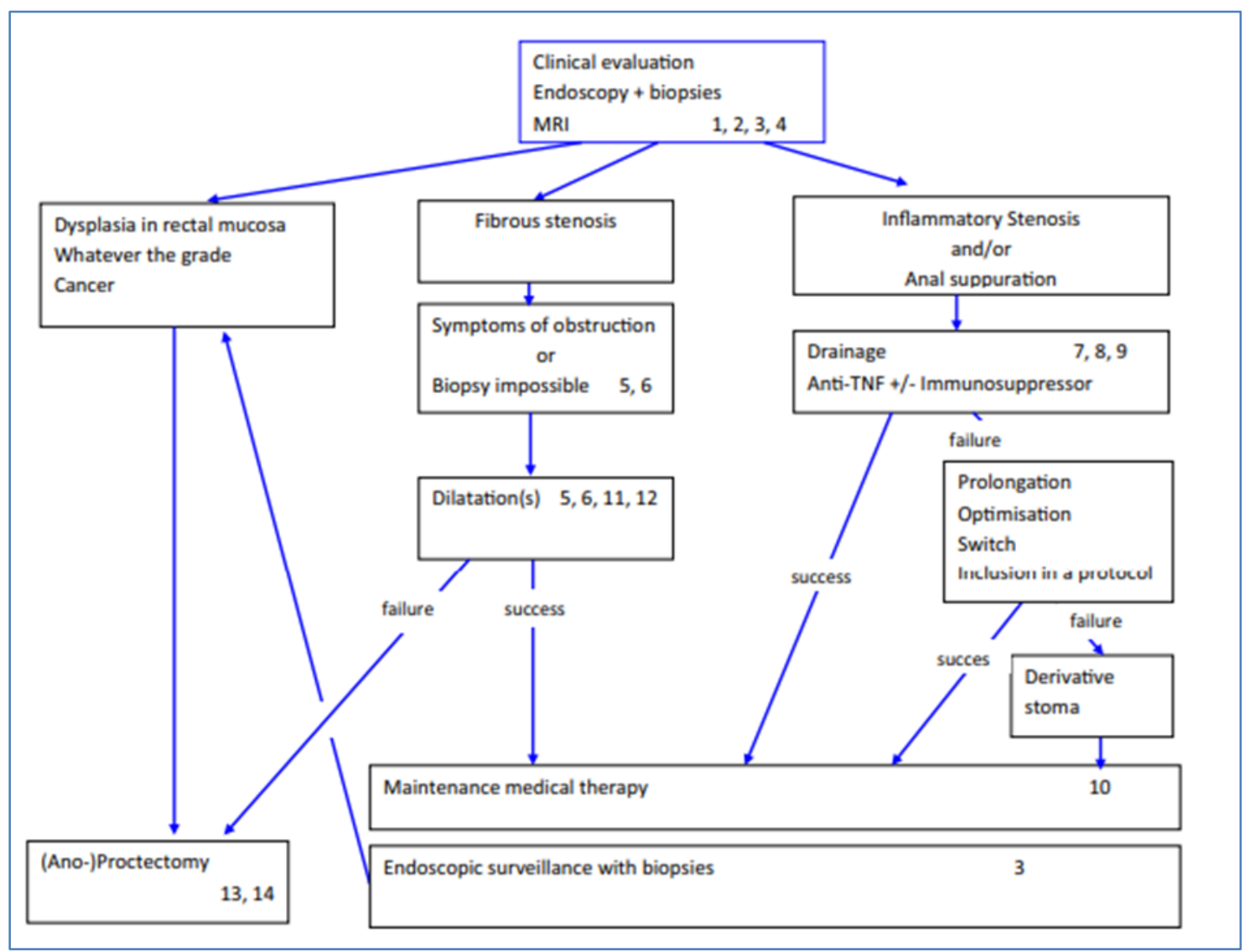

Fig-4: Management of anorectal stenosis associated with Crohn's disease

\section{REFERENCES}

1. Bouguen G, Trouilloud I, Siproudhis L, Oussalah A, Bigard MA, Bretagne JF, Peyrin- Biroulet L. Long- term outcome of non- fistulizing (ulcers, stricture) perianal Crohn's disease in patients treated with infliximab. Alimentary pharmacology \& therapeutics. 2009 Oct;30(7):749-56.

2. Brochard C, Siproudhis L, Wallenhorst T, Cuen D, d'Halluin PN, Garros A, Bretagne JF, Bouguen G. Anorectal stricture in 102 patients with Crohn's disease: natural history in the era of biologics. Alimentary pharmacology \& therapeutics. 2014 Oct;40(7):796-803.

3. Chiarelli M, Guttadauro A, Maternini M, Lo Bianco G, Tagliabue F, Achilli P, Terragni S, Gabrielli F. The clinical and therapeutic approach to anal stenosis.

4. Habr-Gama A, Sobrado CW, Araújo SE, Nahas SC, Birbojm I, Nahas CS, Kiss DR. Surgical treatment of anal stenosis: assessment of 77 anoplasties. Clinics. 2005 Feb;60(1):17-20.

5. Brochard Charlène, Bouguen Guillaume, Wallenhorst Timothée, d'Halluin Pierre- Nicolas, Bretagne Jean-François, Siproudhis Laurent.P292 Sténoses anorectales dans la maladie de Crohn : régressent-elles à l'ère des Biotherapies

6. Fields S, Rosainz L, Korelitz BL. Rectal strictures in Crohn's disease and coexisting perirectal complications. Inflamm Bowel Dis. 2008; 14: 2931.
7. Toy LS, Scherl EJ, Kornbluth A. Complete bowel obstruction following initial response to infliximab therapy for crohn's disease: A series of a newly described complication. Gastroenterology. 2000;118:A569.

8. Vasilopoulos S, Kugathasan S, Saeian K. Intestinal strictures complicating initially successful infliximab treatment for luminal crohn's disease. Am J Gastroenterol. 2000;95:2503.

9. Lichtenstein GR, Olson A, Travers S, Diamond RH, Chen DM, Pritchard ML, Feagan BG, Cohen RD, Salzberg BA, Hanauer SB, Sandborn WJ. Factors associated with the development of intestinal strictures or obstructions in patients with crohn's disease. Am J Gastroenterol. 2006

10. Bourseau S, Meunier P, Coimbra C, Louis E. La maladie de crohn stenosante: Presentation clinique, diagnostic et modalites de traitement. Revue Médicale de Liège. 2016;71(4):178-83.

11. Caprilli R, Gassull MA, Escher JC, Moser G, Munkholm P, Forbes A, Hommes DW, Lochs H. Angelucci E ea, for the European Crohn's and Colitis Organisation (ECCO). European evidence based consensus on the diagnosis and management of Crohn's disease: special situations. Gut. 2006;55.

12. Colombel JF, Sandborn WJ, Reinisch W, Mantzaris GJ, Kornbluth A, Rachmilewitz D, Lichtiger S, D'Haens G, Diamond RH, Broussard DL, Tang KL, van der Woude CJ, Rutgeerts P, Group SS. 
Infliximab, azathioprine, or combination therapy for crohn's disease. N Engl J Med. 2010;362:138395.

13. Condino G, Calabrese E, Zorzi F, Onali S, Lolli E, De Biasio F, Ascolani M, Pallone F, Biancone L. Anti-tnf-alpha treatments and obstructive symptoms in crohn disease: A prospective study. Dig Liver Dis. 2013;45:258-62.

14. Holtmann M, Wanitschke R, Helisch A, Bartenstein P, Galle PR, Neurath M. [anti-tnf antibodies in the treatment of inflammatory intestinal stenoses in crohns disease]. Z Gastroenterol. 2003;41:11-7.

15. Louis E, Boverie J, Dewit O, Baert F, De Vos M, D;Haens G. Treatment of small bowel subocclusive crohns disease with infliximab: An open pilot study. Acta gastroenterologica Belgica. 2007

16. Echarri A, Gallego J, Ollero V, Porta A, Castro J. Evaluation of safety and effectiveness of adalimumab therapy in symptomatic ileal crohns disease strictures. J Crohns Colitis. 2011;5:A227

17. Urlep D, Orel R. Crohn\&;s disease with anorectal stenosis successfully treated with vedolizumab. World J Pediatr. 2017;13:394-5.

18. Cosnes J, Nion-Larmurier I, Beaugerie L, Afchain $\mathrm{P}$, Tiret E, Gendre JP. Impact of the increasing use of immunosuppressants in crohn's disease on the need for intestinal surgery. Gut. 2005;54:237-41

19. Godeherge P. Management of anoperineal lesions in Crohn's disease.Gastroenterol Clin Biol. 2005; 29: $166-77$
20. Kashkooli SB, Samanta S, Rouhani M, Akbarzadeh S, Saibil F. Bougie dilators: simple, safe and costeffective treatment for Crohn's-related fibrotic anal strictures. Canadian Journal of Surgery. 2015 Oct;58(5):347.

21. Xinopoulos D, Kypreos D, Bassioukas SP, Korkolis D, Mavridis K, Scorilas A, Dimitroulopoulos D, Loukou A, Paraskevas E. Comparative study of balloon and metal olive dilators for endoscopic management of benign anastomotic rectal strictures: clinical and costeffectiveness outcomes. Surgical endoscopy. 2011 Mar 1;25(3):756-63.

22. Dominique Bouchard Recommandations pour la pratique clinique des lésions ano-périnéales de la maladie de Crohn. 2014 POST'U 2015 - Paris

23. Adegbola SO, Pisani A, Sahnan K, Tozer P, Ellul $\mathrm{P}$, Warusavitarne J. Medical and surgical management of perianal Crohn's disease. Annals of gastroenterology. 2018 Mar;31(2):129.

24. Slesser AA, Bhangu A, Bower M, Goldin R, Tekkis PP. A systematic review of anal squamous cell carcinoma in inflammatory bowel disease. Surgical oncology. 2013 Dec 1;22(4):230-7.

25. Sonnenberg A, Genta RM. Epithelial dysplasia and cancer in ibd strictures. J Crohns Colitis. 2015;9:769-75.

26. Bouchard D, Brochard C, Vinson-Bonnet B, Staumont G, Abramowitz L, Benfredj P, Fathallah N, Faucheron JL, Higuero T, Panis Y, de Parades , Siproudhis L2, Laharie D, Pigot F.Tech Coloproctol. 2019 Apr;23(4):353-360. 